\title{
Exploration of anti-breast cancer effects of Terminalia chebula extract on DMBA- induced mammary carcinoma in Sprague Dawley rats
}

Deena Priscilla Henry', Jasmine Ranjan', Rajesh Kumar Murugan', Annapoorani Sivanantham² and Manikandan Alagumuthu ${ }^{3^{*}}$ (i)

\begin{abstract}
Background: Plant extracts are effectively acting as the natural medicinal cocktail, non-side effective, efficacious, and freely available. The present study aimed to unveil the pharmacological and medicinal effects of Terminalia chebula plant extract in 7,12-dimethylbenzanthracene (DMBA)-induced mammary carcinoma in Sprague Dawley rats. The plant extract obtained was subjected to in vivo antioxidant and anticancer studies in various concentrations after an analytical technique such as FTIR, GCMS, and HPLC-based chemo-profiling in Sprague Dawley rats.

Results: Apart from the antiproliferative effect on breast cancer cell line (MCF-7) and normal breast epithelial cells (MCF-10a), we have measured the changes in body weight, along with other tumor parameters such as tumor volume, tumor incidence, tumor weight, tumor burden, serum biochemical parameters, and histopathological findings of breast tissue. As the oxidative stress further enhances the development of cancer, the antioxidant property of the plant extract demonstrates its use against cancer treatment. One hundred fifty milligrams per milliliter $\left(I_{50} 250 \mu \mathrm{g} / \mathrm{mL}\right)$ concentration of the ethanolic extract was vital for the proliferation of MCF-7 cell lines (Fig. 7a). Meanwhile, $300 \mu \mathrm{g} / \mathrm{mL}$ $\left(\mathrm{IC}_{50} 150 \mathrm{\mu g} / \mathrm{mL}\right.$ ) was an effective dose to attain a maximum HDAC inhibition of 78\%. Also, the normal liver and kidney functioning revealed the non-toxicity nature of the plant.
\end{abstract}

Conclusion: Terminalia chebula could be one of the effective naturally obtained anti-breast cancer medications. Isolation and characterization of individual bioactive compounds of T. chebula would be the future perspective.

Keywords: Anti-proliferation, Breast cancer, Dimethylbenzanthracene (DMBA), MCF-7, MCF-10, Phytomedicine, Sprague Dawley rats, Terminalia chebula

\section{Background}

Cancer is one of the major public health burdens in both developed and developing countries that arise due to molecular changes within the cell. The search for a new pharmacotherapy from medicinal plants to treat cancers has considerably progressive. A wide range of researchers who keenly discover synthetic medicines to treat breast cancer

\footnotetext{
* Correspondence: mailtomicromani@gmail.com

${ }^{3}$ School of Biosciences and Technology, Vellore Institute of Technology, Vellore 632014, India

Full list of author information is available at the end of the article
}

[1-6]. But still, the safety is questioned. Plants synthesize numerous medicinally important chemical compounds that are functioning as defensive agents against pathogens and other disease precursors [7-9]. The crude extracts of many plants have been reported to harbor a multi-beneficial effect on diseases and disorders. Most of the recent researches are focusing on obtaining effective anticancer therapeutics [1013]. Breast cancer is the second leading cause of death among women. High rates of breast cancer burden have created a deep impact on society [14-17]. Most breast cancers are estrogen-dependent and there has been a relapse in 
$30-40 \%$ of patients receiving adjuvant tamoxifen therapy. So, resistance to endocrine therapy seems to be a clinical problem [18].

The phytochemical screening of medicinal plants is important in identifying new sources of therapeutically important compounds [19]. Presently, various therapies are available for the treatment of cancer, such as chemotherapy, radiotherapy, besides these expensive therapies phytotherapy plays a significant role in the treatment of cancer [20]. The main aim of our present research work is to determine the anticancer potential of the ethanolic extract of the fruits of Terminalia chebula. It is generally known as black or chebulic myrobalan, native to South Asia [21]. Anticancer and antiulcer effects of T. chebula fruits were previously evaluated in a rat model [22-24]. There exists a strong relationship between cancer and oxidative stress and many reports dealing with the antioxidant properties of $T$. chebula in a recent decade [2528 . So, the effect of antioxidant enzymes investigated with liver and kidney toxicity profile analysis.

\section{Methods}

Plant habitat, plant material, and extract preparation

The focus of the study area situates between the two districts of Salem and Tiruchirappalli of Tamil Nadu, India. The hills lie between 78.31 longitudes and 11.28 latitude, the plant found in the selective area of Pachamalai hills, Tamil Nadu, India. The fruits of Terminalia chebula Retz were obtained from the Pachamalai hills of the Tiruchirappalli district. The fruits identified by the help of Dr. John Britto, Director, Rapinet Herbarium, Department of Botany, St. Joseph College, Trichy but a voucher specimen of this material has not been deposited. The experiment was designed by choosing low, moderate, high, and below the lethal or toxic dose to evaluate the comparative effect of the extract. The oral $\mathrm{LD}_{50}$ value of plant extract in the case of SD rats was found to be 800 $\mathrm{mg} / \mathrm{kg}$. Based on the MTT assay, the $\mathrm{IC}_{50}$ value of ethanolic extract was found to be $334.54 \mu \mathrm{g} / \mathrm{ml}$.

\section{Analytical techniques-based chemo- profiling-chromatography and mass spectrometry}

All organic chemicals and solvents required for all assays and biological studies procured from Sigma-Aldrich, Merck, and Himedia. The crude biomass obtained was analyzed with thin layer chromatography (TLC) followed by GCMS (gas chromatography and mass spectrometry). TLC analysis was executed with Merck pre-coated plates (silica gel 60 F254). FTIR (Fourier-transform infra-red spectroscopy) and HPLC (high-performed liquid chromatography) based chemo-profiling was also established. The experiment was executed on an Agilent 1260 series HPLC (Agilent extend-C18 column). Column chromatography is used to extract individual fractions. The individual fractions (single spot in TLC) were subjected to NMR (nuclear magnetic resonance) studies. GC-MS library (NIST) search result-based chemo profiling was taken an account to confirm the single product by comparing the molecular formula and molecular weight in comparison with $r f$ values obtained from TLC experiments. Direct methods and drawn using the ChemDraw 15.0 software, solved the structures.

\section{Animal study}

For the experiments, 21 days old female Sprague Dawley rats of $65-70 \mathrm{~g}$ were used. All rats were kept at room temperature of $22{ }^{\circ} \mathrm{C}$ under $12 \mathrm{~h}$ light $/ 12 \mathrm{~h}$ dark cycle in the animal house. Rats were fed with standard food. "Principles of laboratory animal care" (NIH publication No. 85-23, revised 1985) were followed or comply with standards equivalent to the UKCCCR guidelines for the welfare of animals in experimental neoplasia [29]. All animals were euthanized using a chemical method (chloroform).

\section{Preparation of DMBA and experimental design for treatment-oriented study}

The DMBA was purchased from Sigma Chemicals, Mumbai, India; DMBA was stored at $-20{ }^{\circ} \mathrm{C}$ to prevent its decomposition. The tamoxifen citrate (standard drug) dissolved in a $0.2-\mathrm{ml}$ peanut oil vehicle. Experimental rats were divided into 5 groups of six animals each. Table 1 describes the divided animal group along with other experimental design parameters. A tumor formed animals selected to given treatment for 30 days [30]. To all the 24 animals, except control group was induced mammary carcinogen $(25 \mathrm{mg} / \mathrm{kg})$ by single gastric intubation in $1 \mathrm{ml}$ olive oil, during which the Latency period (the number of days between the DMBA injection and the appearance of the first tumor in each rat) was noted. The tumor was identified by palpation. A tumor formed animals were selected for treatment for 30 days.

\section{Induction of cancer and experimental design for the treatment-oriented study}

On the 31st day, the animals were anesthetized, blood was collected through the retro-orbital sinus and used for the estimation of hematological parameters and then the collected blood was centrifuged and the serum was collected [31]. The collected serum was used to study the biochemical parameters. After the blood collection, animals were sacrificed through cervical decapitation, and the entire liver and kidney were perfused immediately with ice-cold $0.9 \%$ sodium chloride, thereafter, carefully removed, trimmed free of extraneous tissue finally the mammary tumors were excised out and the parameters such as tumor incidence (\% of animals that develop at least one tumor), tumor burden (average 
Table 1 Animal study design details

\begin{tabular}{ll}
\hline Animal groups & Treatment \\
\hline Group I & Control rats were given only saline \\
Group II & Rats given DMBA $(25 \mathrm{mg} / \mathrm{kg})$ was induced by single gastric intubation in $1 \mathrm{ml}$ olive oil \\
Group III & Rats treated with DMBA $(25 \mathrm{mg} / \mathrm{kg})$ was induced by single gastric intubation in $1 \mathrm{ml}$ olive oil + tamoxifen citrate $10 \mathrm{mg} / \mathrm{kg}(P O)$ \\
Group IV & Rats treated with DMBA $(25 \mathrm{mg} / \mathrm{kg})$ was induced by single gastric intubation in $1 \mathrm{ml}$ olive oil + extract $250 \mathrm{mg} / \mathrm{kg}$ \\
Group V & Rats treated with DMBA $(25 \mathrm{mg} / \mathrm{kg})$ was induced by single gastric intubation in $1 \mathrm{ml}$ olive oil + extract $500 \mathrm{mg} / \mathrm{kg}$ \\
\hline
\end{tabular}

number of tumor/animal), tumor volume, tumor weight, and histopathological effects were studied.

\section{Histopathology}

Thin pieces of 3 to $5 \mathrm{~mm}$ thickness were collected from tissues showing gross morbid changes along with normal tissue. Kept the tissue in fixative (10\% formalin) for $24-48$ $\mathrm{h}$ at room temperature. Deparaffinized the section by xylol 5 to $10 \mathrm{~min}$ and removed xylol by absolute alcohol [32, 33]. The cleaned section was stained with hematoxylin for 3-4 min and then counterstained with $0.5 \%$ eosin until the section appears light pink 15 to $30 \mathrm{~s}$. Blotted and dehydrated in alcohol and cleared with xylol 15 to $30 \mathrm{~s}$. Mounted on a Canada balsam or DPX mutant and kept the slide dry and remove air bubbles.

\section{In vivo antioxidant activity}

The animals were sacrificed after treatment. Liver samples were isolated and washed with normal saline and stored for $12 \mathrm{~h}$ for in vivo antioxidant studies [34]. The separated liver was homogenized with motor-driven Teflon coated homogenizer in ice-cold $10 \%(\mathrm{w} / \mathrm{v}) 0.1 \mathrm{M}$ Tris- $\mathrm{HCl}$ buffer $\mathrm{pH} 7.4$ to get $10 \%$ homogenate. The homogenate was centrifuged at $10,000 \mathrm{rpm}$ for $10 \mathrm{~min}$ at $5{ }^{\circ} \mathrm{C}$. The supernatant was collected and used for following in vivo studies.

\section{Enzymatic anti-oxidant activity}

Estimation of superoxide dismutase (SOD) activity was carried out by using $0.5 \mathrm{ml}$ of supernatant tissue homogenate added to $1.5 \mathrm{ml}$ of carbonate buffer $\mathrm{pH} 10.2,0.5 \mathrm{ml}$ of 0.1 $\mathrm{Mm}$ EDTA, and $0.4 \mathrm{ml}$ of epinephrine then OD read at $480 \mathrm{~nm}$. The activity of SOD was expressed as units/min/ mg protein. One unit of the enzyme is defined as the amount of enzyme, which inhibits the rate of adrenaline autooxidation by $50 \%$ [35]. Estimation of catalase activity was analyzed using an assay mixture contained $4 \mathrm{ml}$ of hydrogen peroxide, $5 \mathrm{ml}$ of phosphate buffer, and $1 \mathrm{ml}$ of homogenate. One milliliter portions of the reaction mixture were withdrawn and blown into $2 \mathrm{ml}$ of dichromate/acetic acid reagent at $1 \mathrm{~min}$ intervals. Then the mixture was incubated for $30 \mathrm{~min}$ later, the OD was measured at $570 \mathrm{~nm}$. The activity of catalase was expressed as $\mu$ mole of the $\mathrm{H}_{2} \mathrm{O}_{2}$ consume/mg protein [36]. To estimate glutathione peroxidase $(\mathrm{GPx})$ activity, a reaction mixture consisted of
$0.2 \mathrm{ml}$ each of EDTA, sodium azide, $\mathrm{H}_{2} \mathrm{O}_{2}, 0.4 \mathrm{ml}$ of phosphate buffer, $0.1 \mathrm{ml}$ homogenate/mitochondria and was incubated at $37^{\circ} \mathrm{C}$ at different time intervals. The reaction was arrested by the addition of $0.5 \mathrm{ml}$ of TCA and the tubes were centrifuged at $2000 \mathrm{rpm}$. To $0.5 \mathrm{ml}$ of supernatant, 4 $\mathrm{ml}$ of disodium hydrogen phosphate, and $0.5 \mathrm{ml}$ DTNB were added and the color developed was read at $420 \mathrm{~nm}$ immediately. The activity of GPx was expressed as $\mu$ moles of glutathione oxidized/mg protein [37].

\section{Non-enzymatic anti-oxidant activity}

Estimation of reduced glutathione (GSH) activity carried out using $1 \mathrm{ml}$ of the homogenated precipitate. With $1 \mathrm{ml}$ of TCA and the precipitate was removed by centrifugation. To $0.5 \mathrm{ml}$ of supernatant, $2 \mathrm{ml}$ of DTNB was added and the total volume was made up to $3 \mathrm{ml}$ with phosphate buffer. The absorbance was read at $412 \mathrm{~nm}$. The level of glutathione was expressed as $\mu \mathrm{g} / \mathrm{mg}$ protein [38]. In brief, $0.1 \mathrm{ml}$ of tissue homogenate (Tris- $\mathrm{HCl}$ buffer, $\mathrm{pH} 7.5$ ) was treated with $2 \mathrm{ml}$ of 1:1:1 ratio TBA-TCA- $\mathrm{HCl}$ reagent (thiobarbituric acid $0.37 \%, 0.25 \mathrm{~N} \mathrm{HCl}$, and $15 \% \mathrm{TCA}$ ) and placed in the water bath for $15 \mathrm{~min}$, cooled. The absorbance of the clear supernatant was measured against reference blank at $535 \mathrm{~nm}$. The level of lipid peroxides was expressed as nmoles of MDA formed/mg protein [39]. Estimation of ascorbic acid (vitamin C) was conducted by adding $0.5 \mathrm{ml}$ of water and $1 \mathrm{ml}$ of TCA was added to $0.5 \mathrm{ml}$ of homogenate, mixed thoroughly, and centrifuged. To $1 \mathrm{ml}$ of the supernatant, $0.2 \mathrm{ml}$ of DTC reagent $\left(2,4 \mathrm{DNPH}\right.$, thiourea, $\left.\mathrm{CuSO}_{4}\right)$ was added and incubated at $37^{\circ} \mathrm{C}$ for $3 \mathrm{~h}$. Then $1.5 \mathrm{ml}$ of sulfuric acid was added, mixed well, and the solutions were allowed to stand at room temperature for another $30 \mathrm{~min}$. The color developed was read at $520 \mathrm{~nm}$. The level of ascorbic acid was expressed as $\mu \mathrm{g} / \mathrm{mg}$ protein [40].

\section{Determination of serum biochemical parameters for the liver function and aspartate aminotransferase (AST)/SGOT} The serum collected after centrifugation of collected blood was analyzed for various biochemical parameters like SGOT, SGPT, and ALP. Serum glutamate oxaloacetate transaminase (SGOT) catalyzes the transamination of L-aspartate and $\alpha$-ketoglutarate to form oxaloacetate and L-glutamate. Oxaloacetate formed is coupled with 2, 4-dinitrophenylhydrazine (DNPH) to form a hydrazone, 
a brown-colored complex in an alkaline medium that can be measured calorimetrically [41].

AST (GOT) activity in IU/L = [(Absorbance of the test -Absorbance of control)/(Absorbance of standard-Absorbance of blank)] $\times$ concentration of the standard

\section{Determination of alanine aminotransferase (ALT)/SGPT and alkaline phosphatase (ALP)}

Serum glutathione peroxidase (SGPT) catalyzes the transamination of $\mathrm{L}$-alanine and $\alpha$ ketoglutarate to form pyruvate and L-glutamate. Pyruvate so formed is coupled with 2,4-dinitrophenylhydrazine to form a corresponding hydrazone, a brown-colored complex in an alkaline medium that can be measured calorimetrically [41].

ALT (GPT) activity in IU/L) $=[$ (Absorbance of a test -Absorbance of control)/(Absorbance of standard-Absorbance of blank)] $\times$ concentration of the standard

Alkaline phosphatase from serum converts phenyl phosphate to inorganic phosphate and phenol at $\mathrm{pH}$ 10.0. Phenol so formed reacts in an alkaline medium with 4aminoantipyrine in presence of the oxidizing agent potassium ferricyanide and forms an orange-red colored complex, which can be measured spectrometrically. The color intensity is proportional to the enzyme activity [42].

ALP $=[($ O.D. Test-O.D. Control $) /($ O.D. Standard-O.D. Blank) $] \times 10$

\section{Colorimetric histone deacetylase activity (HDAC) assay}

A commercial HDAC assay kit was used to determine the effect of HDAC inhibition potential of T. chebula extracts. The experimental protocol was followed as per the manufacturer's instructions (BioVision, Inc., USA). The different amounts of extracts $(0.25-5.0 \mathrm{mg} / \mathrm{mL})$ taken in each reaction well, $\mathrm{ddH}_{2} \mathrm{O}$ was added to have a final volume of $150 \mu \mathrm{L}$. For the negative control, $150 \mu \mathrm{L}$ of $\mathrm{ddH}_{2} \mathrm{O}$ was used. In the assay well, $25 \mu \mathrm{L}$ of the HDAC assay buffer and $5 \mu \mathrm{L}$ of the HDAC substrate was added and mixed thoroughly by pipetting. The mixture was incubated at $37^{\circ} \mathrm{C}$ for $90 \mathrm{~min}$. Further, the reaction was stopped by adding $5 \mu \mathrm{l}$ of developer solution to each reaction well and carefully mixed by pipetting and incubated at $37^{\circ} \mathrm{C}$ for another $30 \mathrm{~min}$. Absorbance was read at $405 \mathrm{~nm}$ on a plate reader (xMARK ELISA reader, BioRad). Calculate sample HDAC activity.

Sample HDAC activity $\left(\mathrm{OD}_{405 \mathrm{~nm}} / \mu \mathrm{g}\right)=\Delta \mathrm{OD}_{405 \mathrm{~nm}}$, sample/sample mass $(\mu \mathrm{g})$

Cell culture conditions and antiproliferative activity assay MCF-cell lines procured from NCCS, Pune, India. All experiments were performed with mycoplasma-free cells. MCF-7 cell line has been authenticated using STR (or SNP) profiling within the last 3 years has been included. The name MCF-7 cell lines are the official name and its Research Resource Identifier (RRID) is Cellosaurus MCF-
7 (CVCL_0031). MCF-7 cells obtained were preserved and maintained in DMEM medium supplemented with 10\% fetal bovine serum, streptomycin $(100 \mu \mathrm{g} / \mathrm{ml})$, and penicillin $(100 \mathrm{U} / \mathrm{ml})$ [43-45]. The cells were further incubated at $37^{\circ} \mathrm{C}$ in a humidified $\left(5 \% \mathrm{CO}_{2}\right)$ atmosphere. Cells were seeded in a 96-well microtiter plate at a cell density of about 5000 cells/well and incubated for $24 \mathrm{~h}$. Sample groups were treated with different concentrations of $T$. chebula extracts $(25-125 \mu \mathrm{g} / \mathrm{mL})$. The extracts were dissolved in $100 \mu \mathrm{L}$ of dimethyl sulfoxide (DMSO) in sterile distilled water containing tubes. Vehicle control groups were added with DMSO (final concentration of $0.05 \%$ ) or $\mathrm{ddH}_{2} \mathrm{O}$. Each concentration of the extract was added to the cultured well in triplicate. DMEM was served as the negative control and doxorubicin $(100 \mu \mathrm{g} / \mathrm{mL})$ was served as a positive control. The cells harvested after confluent $( \pm$ 3 days) were stained using Trypan Blue Dye and assessed further.

\section{Statistical analysis}

All results were compared by performing one-way ANOVA with Dunnett's post test. All the results were stated as a proportion/ratio increase or decrease concerning the control result values. The GraphPad Prism software, version 8.1 was used for all statistical analyses. A variance was deliberated statistically significant if $p \leq 0.05$.

\section{Results}

Effect of ethanolic extract of fruits of $T$. chebula Retz on tumor parameters

Based on the assessment parameters and the results obtained from the tumors excised from all the tested rats, it was found that the tumor volume, tumor weight, tumor burden, and tumor incidence was found to be increased in the DMBA-treated groups when compared with the control group. There was a significant decrease in the abovetabulated tumor parameters in animals administered with tamoxifen and ethanolic extract of $T$. chebula. The decrease was also dose-dependent compared with the two doses used for the study, $500 \mathrm{mg} / \mathrm{kg}$ demonstrated a rapid and significant decrease in tumor volume, tumor weight, and tumor burden, and tumor incidence when compared with DMBA-induced tumor rats (Table 2).

\section{Chemo-profiling through analytical techniques}

Crude mass was analyzed for chemo-profiling by the subject it to various analytical techniques such as FT-IR, GCMS (Ref. Figure S3 for method), and HPLC (Ref. Figure S4 for sample analysis). Table S1 depicts the results of GCMS chemo-profiling (Ref. Figure S1 for obtained GC). The given extract was combusted up to a retention time (RT) of 35 . Within this RT range, the compound peaks started from $2.94,16.26$ to 31.02 . The corresponding peaks were used for the NIST library search, and the obtained 
Table 2 Effect of ethanolic extract of $T$. chebula on tumor parameters

\begin{tabular}{lllll}
\hline Group & Tumor volume $\left(\mathbf{m m}^{\mathbf{3}}\right)$ & Tumor weight $(\mathbf{m g})$ & Tumor burden $(\boldsymbol{n})^{*}$ & Tumor incidence $(\%)$ \\
\hline Group I & $0.00 \pm 0.00^{\mathrm{b}}$ & $0.00 \pm 0.00^{\mathrm{b}}$ & $0.00 \pm 0.00^{\mathrm{b}}$ & $0.00 \pm 0.00^{\mathrm{b}}$ \\
Group II & $0.83 \pm 0.07^{\mathrm{a}}$ & $122.7 \pm 3.01^{\mathrm{a}}$ & $7.83 \pm 0.75^{\mathrm{a}}$ & $6.00 \pm 0.89^{\mathrm{a}}$ \\
Group III & $0.27 \pm 0.07^{\mathrm{ab}}$ & $34.00 \pm 2.36^{\mathrm{ab}}$ & $3.83 \pm 0.75^{\mathrm{ab}}$ & $2.66 \pm 0.51^{\mathrm{ab}}$ \\
Group IV & $0.47 \pm 0.12^{\mathrm{ab}}$ & $66.00 \pm 2.36^{\mathrm{ab}}$ & $5.00 \pm 0.89^{\mathrm{ab}}$ & $5.00 \pm 0.89^{\mathrm{ab}}$ \\
Group V & $0.44 \pm 0.01^{\mathrm{ab}}$ & $54.67 \pm 2.58^{\mathrm{ab}}$ & $4.66 \pm 1.36^{\mathrm{ab}}$ & $4.83 \pm 0.75^{\mathrm{ab}}$ \\
\hline
\end{tabular}

${ }^{*} n$ denotes an average number of tumors per animal; values are expressed as mean \pm S.D

Statistical significance $(p)$ was calculated by one-way ANOVA followed by Tukey's multiple comparison tests

The control group was compared with normal; standard and test groups were compared with control; $P<0.05$ considered significant

compounds were tabulated. The individual compound structures were drawn by the Chemdraw 15.0 software. Starting from phenolic compounds, esters, fatty acids (saturated and unsaturated organic) based compounds were found in the extract (Figure S2a-c). Exactly twelve elevated peaks were remarkably found both in GCMS and HPLC (Fig. 1) analysis.

This shows the resemblance of both chromatography technique results. According to FTIR results (Fig. 2), 3344 and 3201 peaks are indicating $\mathrm{C}-\mathrm{H}$ stretch. The remarkable 2922 and 2852 peaks are representing $\mathrm{C}=\mathrm{N}$ groups availability in the T. chebula extract. $\mathrm{C}=\mathrm{O}$ presence is also recognized by the availability of peak range from 1722 to 1178 .

\section{Histopathology of breast tissue}

In the histopathology reports, the section from breast obtained from normal rats displayed no evidence of malignancy. Tumor-induced rats containing only
DMBA treatment showed an infiltrating neoplasm composed of cells arranged in glands as seen in the picture (Fig. 3). Individual cells were round to oval with moderate eosinophilic cytoplasm and round oval vesicular nuclei with some showing nucleoli. Areas of comedo necrosis were also seen (Fig. 3a). The sections of breast tissue of tamoxifen-treated DMBAinduced SD rats revealed a circumscribed lesion with areas of adenosis and fibrosis. No evidence of malignancy was observed (Fig. 3b). Two hundred fifty milligrams per kilogram of a crude ethanolic extract of fruits of T. chebula-treated DMBA-induced SD rats tissue sections from breast developed circumscribed lesion with diffusing hyperplasia of ducts (adenosis) separated by fibro collagenous stroma. No sign of malignancy was reported (Fig. 3c). A high dose of the crude extract $(500 \mathrm{mg} / \mathrm{kg})$ treated DMBA rat sections revealed a cystic lesion composed of diffused

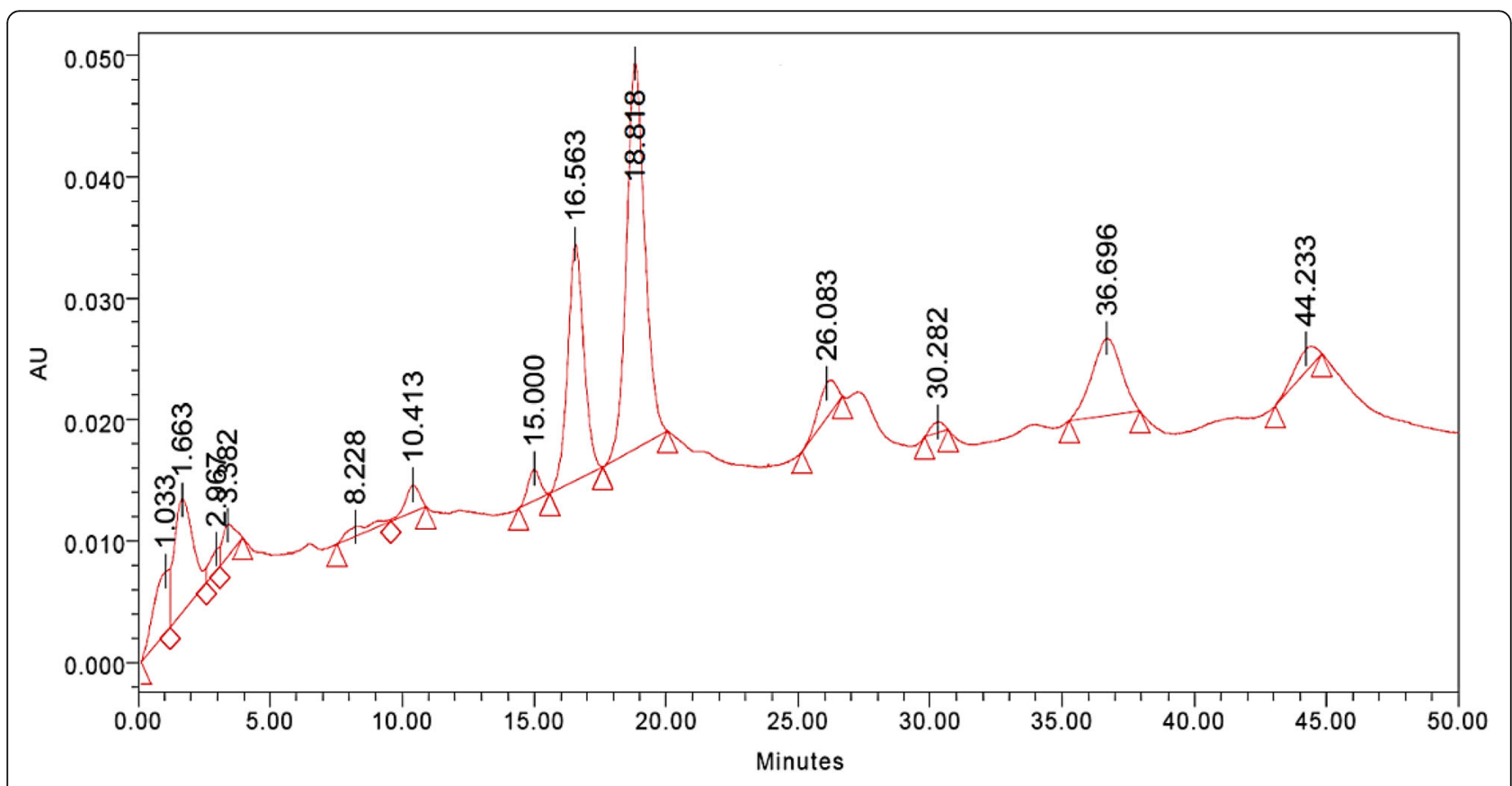

Fig. 1 HPLC peaks obtained for T. chebula extract 


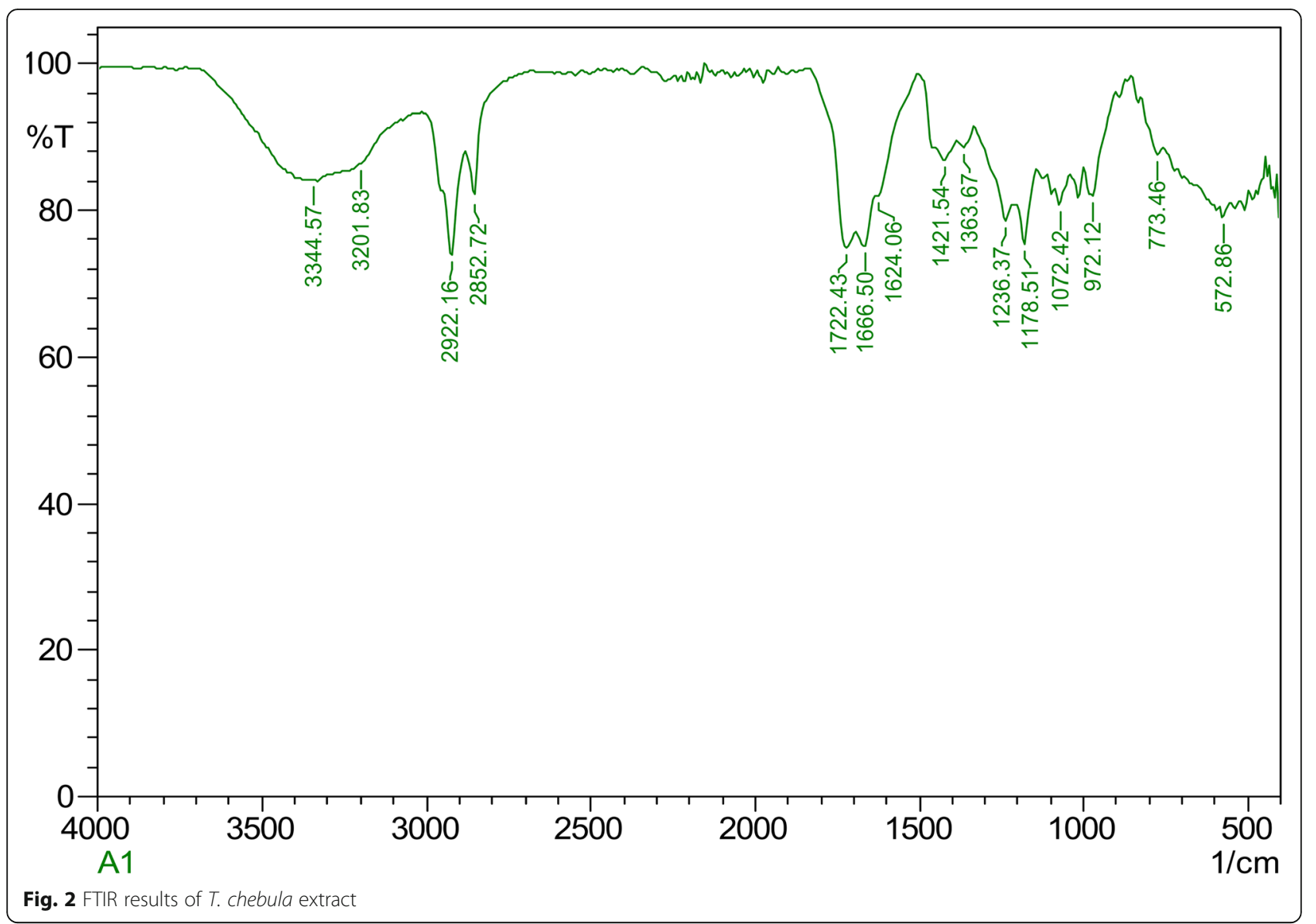

infiltration of neutrophils. Stroma showed congested vessels and fibro-collagenous tissue. No sign of malignancy was seen (Fig. 3d).

\section{In vivo antioxidant activity}

In vivo, antioxidant studies were carried out on DMBAinduced mammary carcinoma in female Sprague Dawley rats because oxidative stress is associated with cancer. The following antioxidants enzymes were determined in the liver tissues of all tested rats. Figure 4 represents all the obtained results.

\section{Effect of ethanolic extract of $T$. chebula on superoxide dismutase (SOD)}

A deep decrease in the SOD level was observed in DMBA-induced rats $3.05 \pm 0.16 \mathrm{unit} / \mathrm{mg}$ compared to normal rats. The decrease seems to be statistically significant. When DMBA-induced rats were treated with T. chebula extract $(250 \mathrm{mg} / \mathrm{kg}$ and $500 \mathrm{mg} / \mathrm{kg})$, the SOD levels increased. When $200 \mathrm{mg} / \mathrm{kg}$ of the extract was administered, the SOD level was $3.78 \pm$ $0.14 \mathrm{unit} / \mathrm{mg}$ and when the extract concentration was increased to $500 \mathrm{mg} / \mathrm{kg}$, there was a change in the SOD level as seen in Fig. 4a (Table S1). A significant increase in SOD was observed in the case of tamoxifen-treated DMBA rats that coincide with the data obtained from the ethanolic extract-treated group.

Effect of ethanolic extract of $T$. chebula on catalase (CAT) A deep decrease of CAT level was observed in DMBAinduced rats $60.67 \pm 1.03 \mathrm{unit} / \mathrm{mg}$ when compared to normal rats. The decrease seems to be statistically significant. When DMBA-induced rats were treated with $T$. chebula extract $(250 \mathrm{mg} / \mathrm{kg}$ and $500 \mathrm{mg} / \mathrm{kg})$, the CAT levels increased. When $200 \mathrm{mg} / \mathrm{kg}$ of the extract was administered, the CAT level was $73.67 \pm 1.63 \mathrm{unit} / \mathrm{mg}$ and when the extract concentration was increased to $500 \mathrm{mg} / \mathrm{kg}$, there was a change in CAT level as seen in Fig. 4b (Table S2). A significant increase in CAT was observed in the case of tamoxifen-treated DMBA rats that coincide with the data obtained from the ethanolic extract-treated group.

\section{Effect of ethanolic extract of $T$. chebula on lipidperoxidase (LPO)}

A deep increase of LPO level was observed in DMBAinduced rats $35.83 \pm 1.47 \mathrm{nMMDA} / \mathrm{g}$ of protein when compared to normal rats. The decrease seems to be 


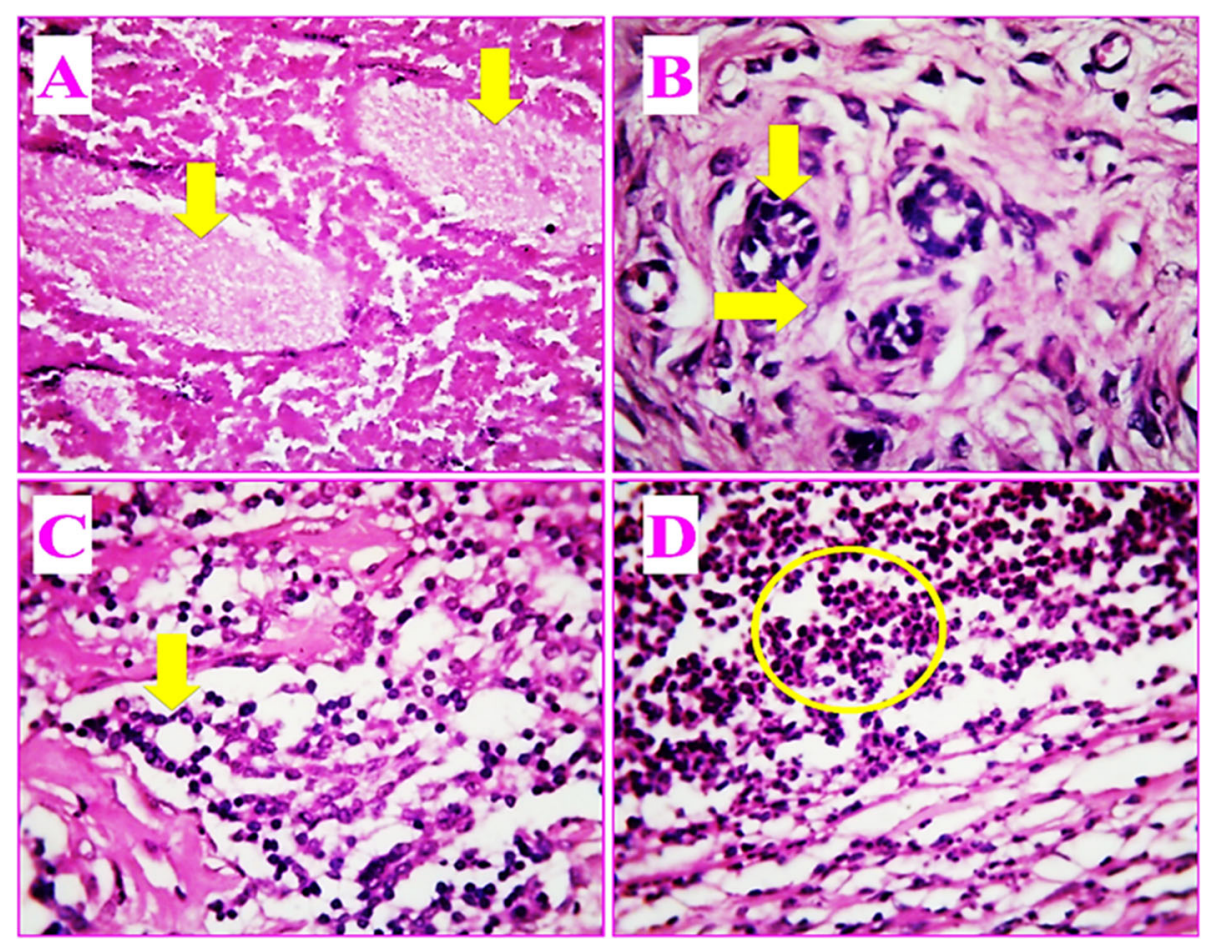

Fig. 3 Histopathology of breast tissues after T. chebula treatment. a A section from breast shows infiltrating ductal carcinoma (down arrows) (group II). b A section from breast shows areas of adenosis (down arrow) and fibrosis (straight arrow) (group III). c A section from the breast shows micro glandular adenosis (down arrow) (group IV). d A section from the breast shows infiltration of neutrophils (group V)

statistically significant. When DMBA-induced rats were treated with $T$. chebula extract $(250 \mathrm{mg} / \mathrm{kg}$ and $500 \mathrm{mg} /$ $\mathrm{kg}$ ), the LPO levels decreased. When $200 \mathrm{mg} / \mathrm{kg}$ of the extract was administered, the LPO level was $25.67 \pm 1.21$ nMMDA/g of protein and when the extract concentration was increased to $500 \mathrm{mg} / \mathrm{kg}$, there was a change in LPO level as seen in Fig. 4c (Table S2). A significant decrease in LPO was observed in the case of tamoxifen-treated DMBA rats that coincide with the data obtained from the ethanolic extract-treated group.

\section{Effect of ethanolic extract of $T$. chebula on glutathione peroxidase (GPx)}

A deep decrease of GPx level was observed in DMBAinduced female SD rats $20.50 \pm 1.04 \mu \mathrm{g}$ of $\mathrm{GSH} / \mathrm{mg}$ of protein when compared to normal rats. The decrease seems to be statistically significant. When DMBAinduced rats were treated with $T$. chebula extract $(250$ $\mathrm{mg} / \mathrm{kg}$ and $500 \mathrm{mg} / \mathrm{kg}$ ), the GPx levels increased. When $200 \mathrm{mg} / \mathrm{kg}$ of the extract was administered, the GPx level was $34.50 \pm 1.64 \mu \mathrm{g}$ of $\mathrm{GSH} / \mathrm{mg}$ of protein and when the extract concentration was increased to $500 \mathrm{mg} / \mathrm{kg}$, there was a change in GPx level as seen in Fig. 4d (Table S1). A significant increase in GPx was observed in the case of tamoxifen-treated DMBA rats that coincides with the data obtained from the ethanolic extract-treated group.
Effect of ethanolic extract of $T$. chebula on reduced glutathione (GSH)

A deep decrease of GSH level was observed in DMBAinduced rats $17.83 \pm 1.32 \mathrm{mg} / \mathrm{g}$ of tissue when compared to normal rats. The decrease was found statistically significant. When DMBA-induced rats were treated with $T$. chebula extract $(250 \mathrm{mg} / \mathrm{kg}$ and $500 \mathrm{mg} / \mathrm{kg})$, the $\mathrm{GSH}$ levels increased. When $200 \mathrm{mg} / \mathrm{kg}$ of the extract was administered, the GSH level was $24.50 \pm 1.87 \mathrm{mg} / \mathrm{g}$ of tissue and when the extract concentration was increased to $500 \mathrm{mg} / \mathrm{kg}$, there was a change in GSH level as seen in Fig. 4e (Table S2). A significant increase in GSH was observed in the case of tamoxifen-treated DMBA rats that coincides with the data obtained from the ethanolic extract-treated group.

Effect of ethanolic extract of $T$. chebula on vitamin C

A deep decrease of vitamin $C$ level was observed in DMBA-induced female SD rats $35.83 \pm 1.47 \mu \mathrm{g} / \mathrm{mg}$ of protein when compared to normal rats. The decrease seems to be statistically significant. When DMBAinduced rats were treated with $T$. chebula extract (250 $\mathrm{mg} / \mathrm{kg}$ and $500 \mathrm{mg} / \mathrm{kg}$ ), the vitamin $\mathrm{C}$ levels decreased. When $200 \mathrm{mg} / \mathrm{kg}$ of the extract was administered, the vitamin $C$ level was $0.66 \pm 0.03 \mu \mathrm{g} / \mathrm{mg}$ of protein and when the extract concentration was increased to 500 $\mathrm{mg} / \mathrm{kg}$, there was a change in LPO level as seen in Fig. 


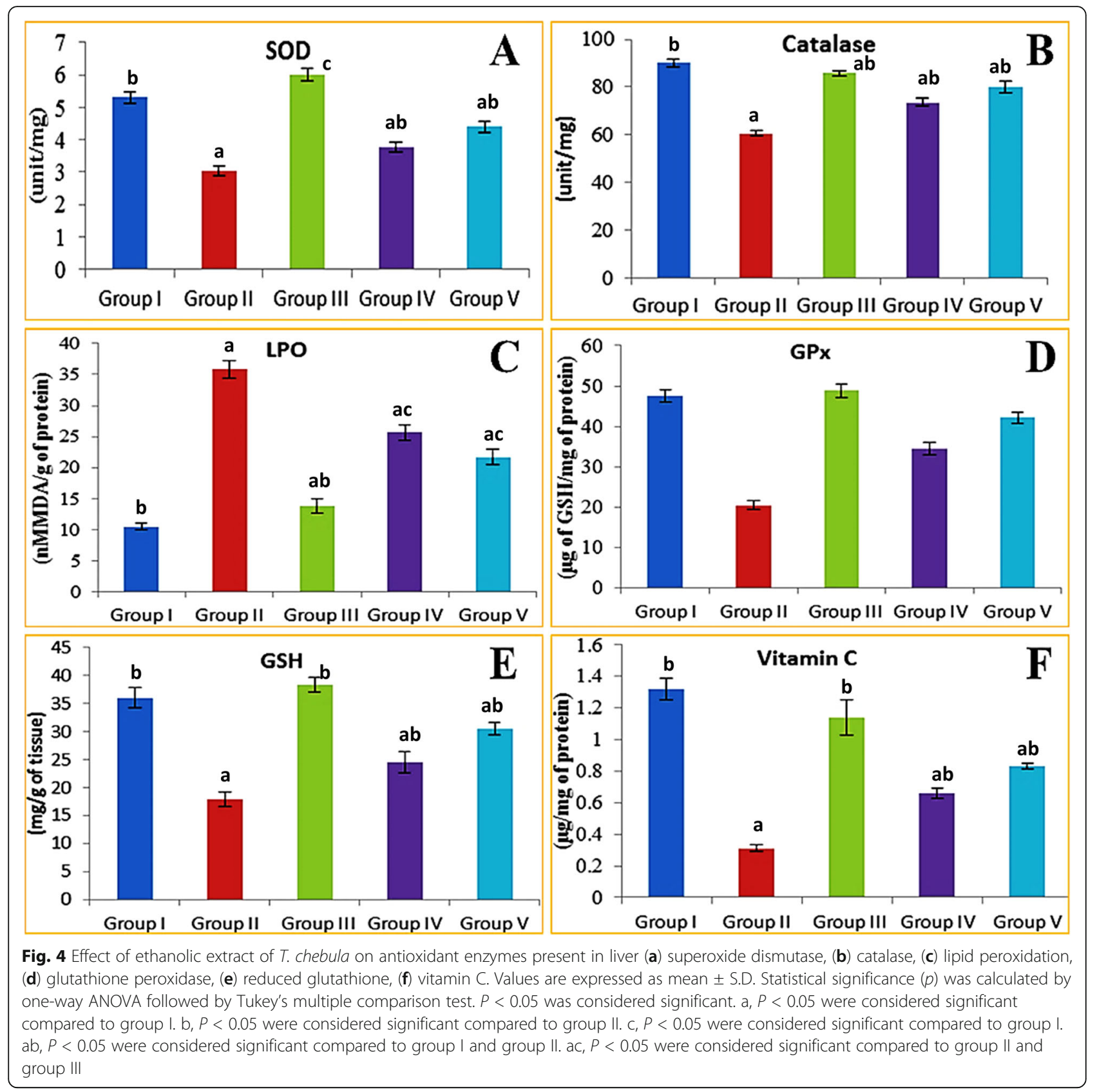

4f (Table S2). A significant increase in vitamin C was observed in the case of tamoxifen-treated DMBA rats that coincide with the data obtained from the ethanolic extract-treated group.

In our study, group II (DMBA-induced rats) showed a significant decrease in SOD, CAT, GSH, and vitamin C levels compared to group I (normal). Conversely, group III (tamoxifen-treated DMBA-induced rats), group IV (ethanolic extract $200 \mathrm{mg} / \mathrm{kg}$ treated rats), and group V (ethanolic extract $500 \mathrm{mg} / \mathrm{kg}$ treated rats) showed a significant increase in the level of antioxidant enzymes such as SOD, CAT, GSH, GPX, and ascorbate levels compared to group II. Also, group II showed a significant increase in LPO enzyme compared to group I. Group III, IV, and V showed a significant decrease in the level of liver LPO when compared to group II.

Effect of $T$. chebula on liver functioning (SGOT, SGPT, and ALP) The present study in DMBA-induced female Sprague Dawley rats represents elevated levels of SGOT, SGPT, and ALP in DMBA induced rats. Figure 5 displays all obtained results of levels of SGOT, SGPT, and ALP in DMBA-induced rats 


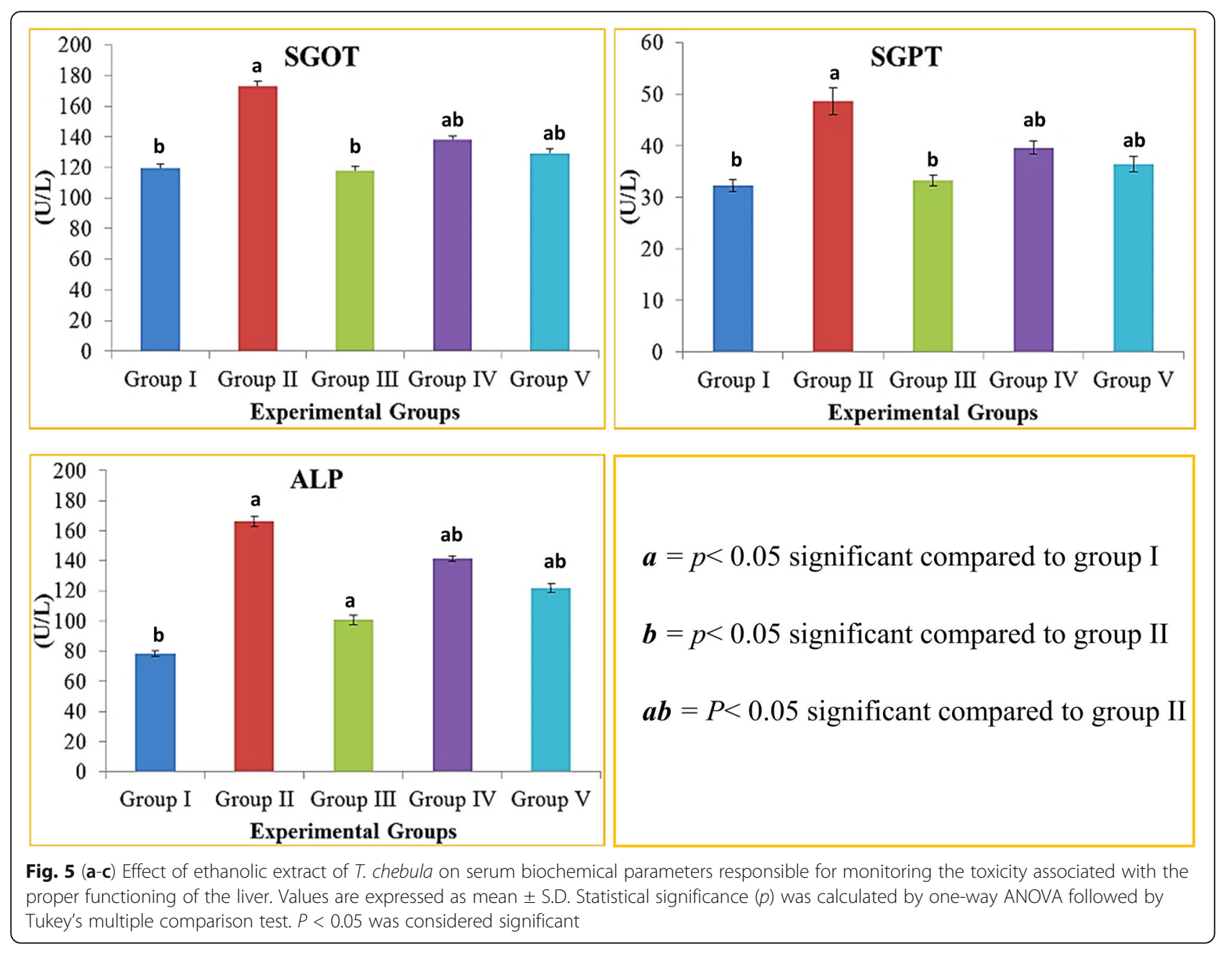

Effect of T. chebula extract on serum glutamic oxaloacetic transaminases (SGOT)

The SGOT level of $119.5 \pm 3.01 \mathrm{U} / \mathrm{L}$ in the normal rats was elevated to $172.9 \pm 3.15 \mathrm{U} / \mathrm{L}$ in DMBA-induced rats. This increase was found to be statistically significant. Tamoxifen-treated rats demonstrated a decrease in SGOT $118.0 \pm 2.75 \mathrm{U} / \mathrm{L}$ when compared to the DMBA-induced group. The SGOT levels were found to be $138.3 \pm 2.16 \mathrm{U} /$ $\mathrm{L}$ and $129.2 \pm 2.99 \mathrm{U} / \mathrm{L}$ (Fig. 5a; Table S3) in $250 \mathrm{mg} / \mathrm{kg}$ and $500 \mathrm{mg} / \mathrm{kg}$ of extract-treated rats respectively.

\section{Effect of T. chebula extract on serum glutamic pyruvic transaminases (SGPT)}

The SGPT level of $32.33 \pm 1.21 \mathrm{U} / \mathrm{L}$ in the normal rat was elevated to $48.67 \pm 2.58 \mathrm{U} / \mathrm{L}$ in DMBA-induced rats. This increase was found to be statistically significant. Tamoxifen-treated rats demonstrated a decrease in SGPT $33.33 \pm 1.03 \mathrm{U} / \mathrm{L}$ when compared to the DMBA-induced group. The SGPT levels were found to be $39.67 \pm 1.21 \mathrm{U} /$ $\mathrm{L}$ and $36.50 \pm 1.51 \mathrm{U} / \mathrm{L}$ (Fig. 5b; Table S3) in $250 \mathrm{mg} / \mathrm{kg}$ and $500 \mathrm{mg} / \mathrm{kg}$ of extract-treated rats respectively.

\section{Effect of ethanolic extract of T. chebula on alkaline} phosphatase (ALP)

The ALP level of $78.57 \pm 1.66 \mathrm{U} / \mathrm{L}$ in the normal rat was elevated to $166.2 \pm 3.54 \mathrm{U} /$ Lin DMBA-induced rats. This increase was found to be statistically significant. Tamoxifen-treated rats demonstrated a decrease in ALP $100.7 \pm 3.38 \mathrm{U} / \mathrm{L}$ when compared to the DMBA-induced group. The ALP levels were found to be $141.3 \pm 1.36 \mathrm{U} /$ $\mathrm{L}$ and $121.8 \pm 2.92 \mathrm{U} / \mathrm{L}$ (Fig. 5c; Table S3) in $250 \mathrm{mg} / \mathrm{kg}$ and $500 \mathrm{mg} / \mathrm{kg}$ of extract-treated rats respectively.

Effect of ethanolic extract of $T$. chebula on kidney functioning Effect of ethanolic extract of T. chebula on urea

Urea level of $22.17 \pm 2.04 \mathrm{mg} / \mathrm{dL}$ in the normal rat was elevated to $39.70 \pm 1.37 \mathrm{mg} / \mathrm{dL}$ in DMBA-induced rats. This increase was found to be statistically significant. Tamoxifentreated rats demonstrated a decrease in urea $24.03 \pm 1.79$ $\mathrm{mg} / \mathrm{dL}$ compared to the DMBA-induced group. Urea levels were found to be $29.33 \pm 1.86 \mathrm{mg} / \mathrm{dL}$ and $23.43 \pm 1.34 \mathrm{mg} /$ $\mathrm{dL}$ in $250 \mathrm{mg} / \mathrm{kg}$ and $500 \mathrm{mg} / \mathrm{kg}$ of ethanolic extract-treated rats respectively (Fig. 6a; Table S4). 


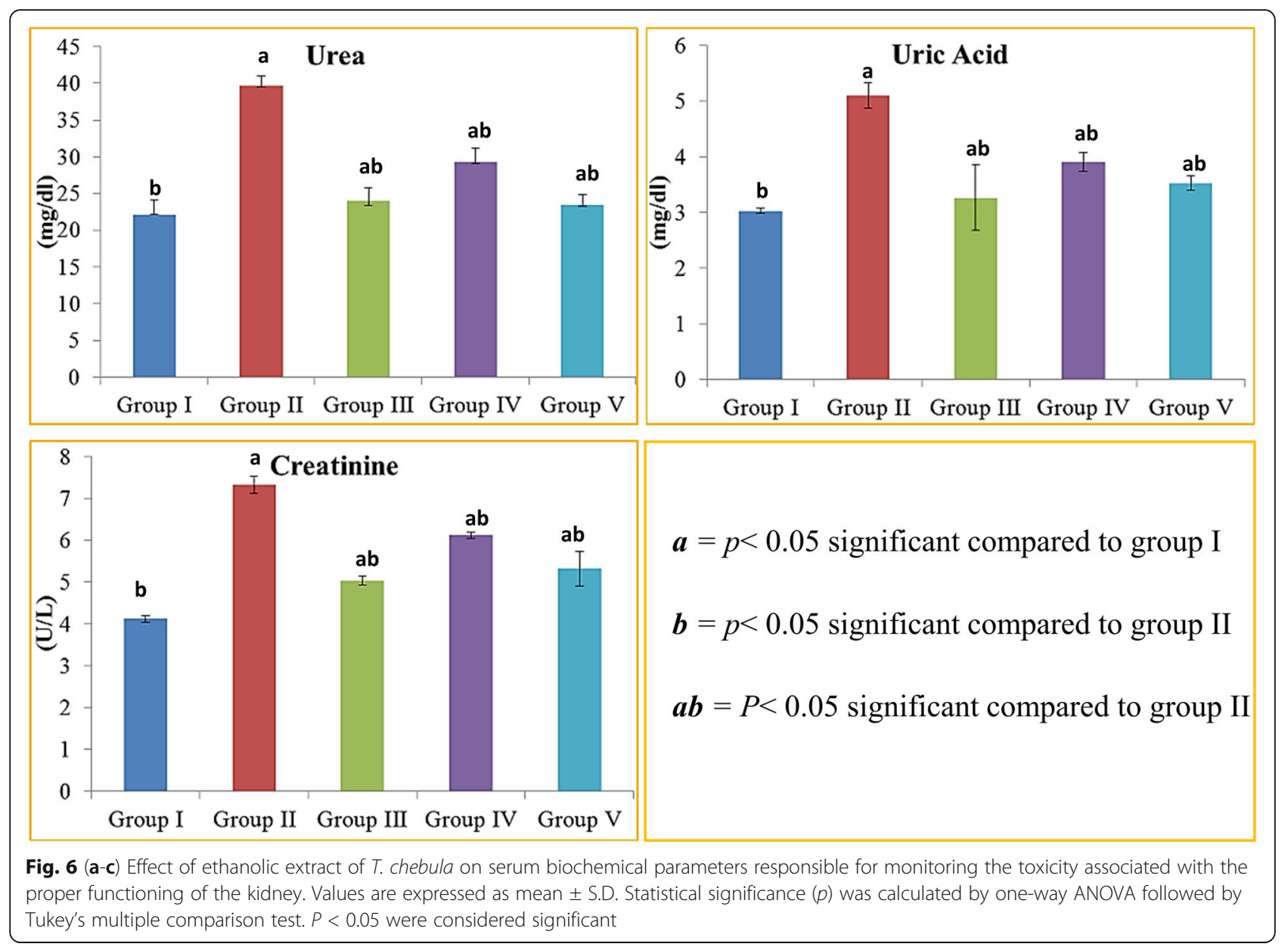

Effect of ethanolic extract of T. chebula on uric acid

The uric acid level of $3.03 \pm 0.05 \mathrm{mg} / \mathrm{dL}$ in the normal rat was elevated to $5.10 \pm 0.23 \mathrm{mg} / \mathrm{dL}$ in DMBA-induced rats. This increase was found to be statistically significant. Tamoxifen-treated rats demonstrated a decrease in uric acid $3.26 \pm 0.59 \mathrm{mg} / \mathrm{dl}$ when compared to DMBA-induced group. The uric acid levels were found to be $3.90 \pm 0.17$ $\mathrm{mg} / \mathrm{dL}$ and $3.53 \pm 0.13 \mathrm{mg} / \mathrm{dL}$ in $250 \mathrm{mg} / \mathrm{kg}$ and $500 \mathrm{mg} /$ $\mathrm{kg}$ of ethanolic extract-treated rats respectively (Fig. 6b; Table S4).

\section{Effect of ethanolic extract of $T$. chebula on creatinine}

The creatinine level of $4.12 \pm 0.07 \mathrm{mg} / \mathrm{dL}$ in the normal rat was elevated to $7.32 \pm 0.21 \mathrm{mg} / \mathrm{dL}$ in DMBA-induced rats. This increase was found to be statistically significant. Tamoxifen-treated rats demonstrated a decrease in urea 5.03 $\pm 0.11 \mathrm{mg} / \mathrm{dL}$ when compared to DMBA-induced group. The urea levels were found to be $6.12 \pm 0.08 \mathrm{mg} / \mathrm{dL}$ and 5.32 $\pm 0.41 \mathrm{mg} / \mathrm{dL}$ in $250 \mathrm{mg} / \mathrm{kg}$ and $500 \mathrm{mg} / \mathrm{kg}$ of ethanolic extract-treated rats respectively (Fig. 6c; Table S4). Thus, the different doses of ethanolic extract of $T$. chebula proved to be much effective when compared with tamoxifen.

\section{HDAC inhibition and anti-proliferative effects of fruit ethanolic extract of $T$. chebula}

The results depicted in Fig. 7 illustrates the HDAC inhibition and anti-proliferative effect of ethanolic extract of $T$. chebula. One hundred fifty milligrams per milliliter ( $\mathrm{IC}_{50} 250 \mu \mathrm{g} / \mathrm{mL}$ ) concentration of ethanolic extract was vital for the proliferation of MCF-7 cell lines (Fig. 7a). Meanwhile, $300 \mu \mathrm{g} / \mathrm{mL}\left(\mathrm{IC}_{50} 150 \mu \mathrm{g} / \mathrm{mL}\right.$ ) was an effective dose to attain a maximum HDAC inhibition of $78 \%$. Figure 7c (untreated) and Fig. 7d (treated up to $350 \mu \mathrm{g} /$ $\mathrm{mL}$ of extract) illustrates the effect of the treatment of the ethanolic extract of $T$. chebula on MCF-7 cells. These remarkable results denote the effective medicinal values in the treatment of breast cancer.

\section{Discussion}

In the case of cancer, the transport function carried out by cell organelles including hepatocyte undergo alteration leading to the release of enzymes owning to altered permeability of the plasma membrane [46]. Recent researches have reported an increase in tumor volume along with elevated levels of SGOT, SGPT, and ALP in tumor-induced rats [42]. ALP's activity affects membrane permeability 


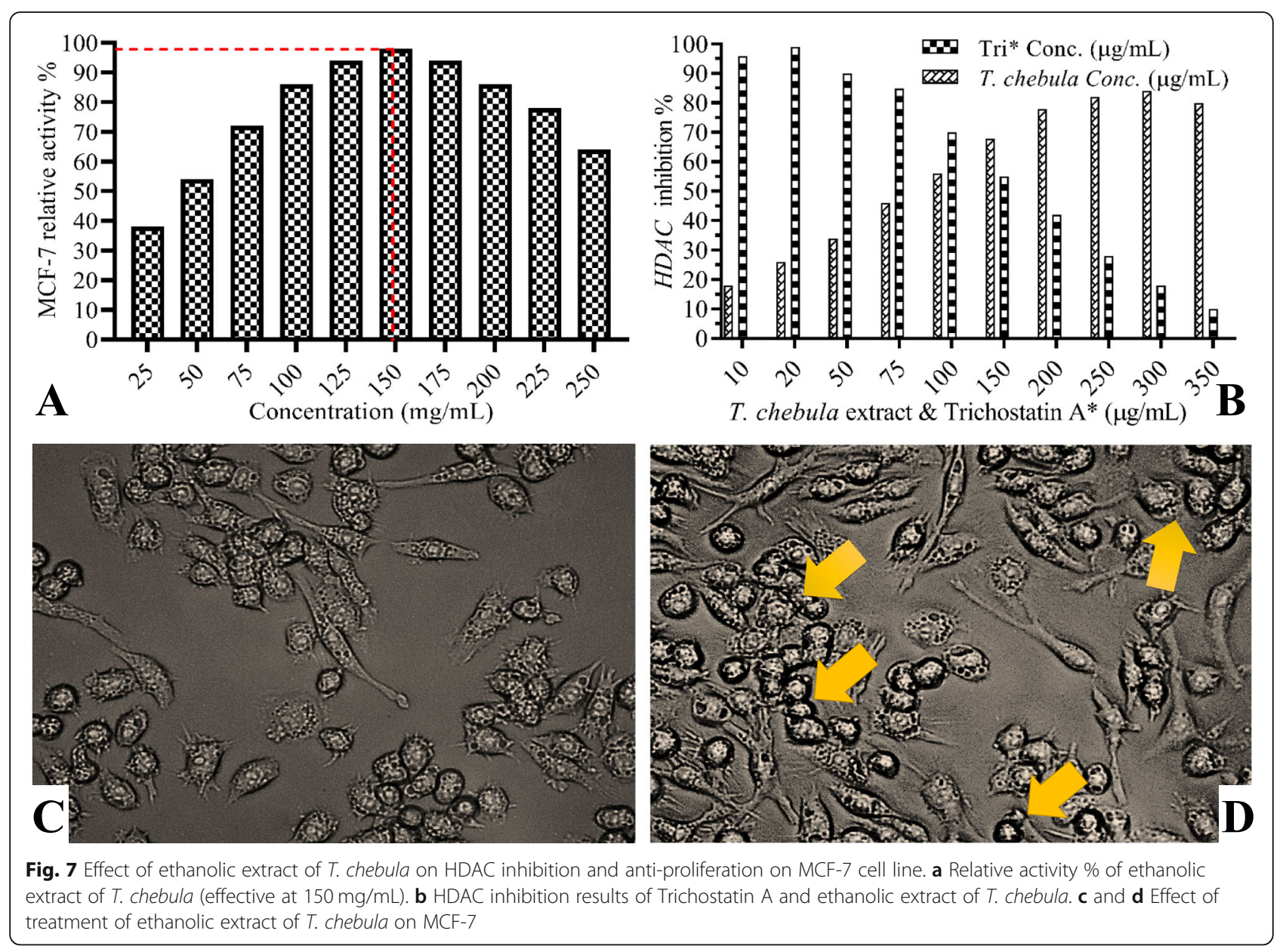

and transport of metabolites and acts as the specific tumor marker during diagnosis and early detection. It plays a key role not only in the transfer of metabolites across the cell membrane but also in the synthesis of proteins and glycogen metabolism. In our study, the ethanolic extract of the fruits of $T$. chebula-mediated suppression of elevated levels of ALP in DMBA-induced rats suggests the possibility of this plant extract to stabilize the plasma membrane [47]. In DMBA-induced rats, treatment with the $T$. chebula showed a $40 \%$ tumor volume inhibition and the difference seems to be statistically significant $(p<0.05)$. This demonstrates the tumor growth inhibition potential of the crude extract as reported earlier [48]. The present study of ethanolic extract also demonstrated a dose-dependent activity, which was incomparable to other studies $[49,50]$.

In a recent investigation, the ethanolic extract of Argemone Muxicana L (Papaveraceae), Polyathia longifolia (Annonaceae), Terminalia bellerica, and Terminalia chebula (Combretaceae) were tested for anticancer and antimicrobial activity in vitro [51]. Usage of $80 \%$ aqueous acetone extract of cranberry increased apoptosis of MCF-7 cells by $25 \%$ at a concentration of $50 \mathrm{~g} / \mathrm{L}$ with significant arrest in the G1 phase. Evidence suggests that cranberry phytochemicals have a deleterious effect on certain types of tumors by inducing apoptosis, inhibiting proliferation, and colony formation [52]. Another work demonstrated that extracts of the plant $T$. occidentalis decrease tumor weight and volume compared to cancerous control with enhanced body weight and longevity compared to cancerous control and doxorubicin-treated groups [53].

Though some differences are there between rat mammary adenocarcinoma, the degrees of morphological aggressiveness, and other parallel correlations observed between these two parameters suggest DMBA-induced rat model as a current tool for understanding breast cancer [54]. Previously, the anti-tumorigenic potential of $T$. chebula has been assessed, the extract in chemically induced Swiss albino skin tumor mice model [55]. Recently, a triherbal formulation of seed coats of $T$. chebula, dry seeds of $E$. ganitrus, and leaves of $P$. cineraria has reported treating DMBA-induced mammary carcinoma in female Sprague Dawley rats [56]. In the present study, deviated from the abovementioned studies, we have used the ethanolic extract from $T$. chebula fruit to treat DMBA-induced mammary carcinoma in female 
Sprague Dawley rats. All these scientific data support the idea of the use of plant-based compounds in the treatment of cancer specifically mammary carcinoma.

\section{Conclusion}

In conclusion, we have been able to arrive at a better understanding of the use of T. chebula as a carrier of the potential anticancer agent. Chemo-profiling through analytical techniques demonstrated the presence of efficacious bioactive compounds in $T$. chebula extract. The evidence of our in vivo study serves to support our ideology that if further explored this may lead to the development of nouveau drugs of plant origin that could claim medically economic significance beneficial to save the lives of distressed and oppressed mankind.

\section{Supplementary information}

The online version contains supplementary material available at https://doi. org/10.1186/s43094-020-00124-z.

Additional file 1: Table S1. GCMS based chemo-profiling of $T$. chebula Retz extract. Table S2. Effect of ethanolic extract of T. chebula Retz on antioxidant enzymes. Table S3. Effect of ethanolic extract of T.chebula Retz on biochemical parameters. Table S4. Effect of ethanolic extract on biochemical parameters. Figure S1. GCMS results of Terminalia chebula. Figure S2a. Chemoprofiling of T. chebula extract through GCMS-NIST Library search. Figure S2b. Chemoprofiling of T. chebula extract through GCMS-NIST Library search. Figure S2c. Chemoprofiling of T. chebula extract through GCMS-NIST Library search. FigureS3. GCMS method and parameters adopted. FigureS4. HPLC sample information.

\section{Acknowledgements}

The authors are deeply acknowledging Dept. of Biotech., Bishop Heber College, Tiruchirappalli- 620017, India, for all support. Dr. Sivakumar A, HOD, Dept. Biosciences, VIT University, Vellore-632014, India, acknowledge all his extended supports in all aspects of this research.

\section{Plant authentication}

The fruits of Terminalia chebula Retz were obtained from the Pachamalai hills of the Tiruchirappalli district. The fruits identified by the help of Dr. John Britto, Director, Rapinet Herbarium, Department of Botany, St. Joseph College, Tiruchirappalli, India.

\section{Authors' contributions}

MA has designed and completed data acquisition, analysis, interpretation, and drafted the work; RK processed the analytical chemistry work; JR substantively revised the draft; AS carried out in vitro antioxidant assay of plant extract; DPH involved in plant extract preparation, bioactivity, and animal study evaluations. All authors have read and approved the manuscript.

\section{Funding}

No funding sources for this submission

\section{Availability of data and materials}

Data and material are available upon request

\section{Ethics approval and consent to participate}

All animal procedures performed after approval from the IAEC (Institution of the animal ethical committee) and following the recommendations for the proper care and use of laboratory animals (IAEC NO: KMCRET/Ph.D/11/2014-2015).

\section{Consent for publication}

Not applicable

\section{Competing interests}

All authors declare that they have no competing interests

\section{Author details}

${ }^{1}$ Department of Biotechnology, Bishop Heber College, Tiruchirappalli 620017, India. ${ }^{2}$ Dr. Umayal Ramanathan College for Women, Alagappa University, Karaikudi 630001, India. ${ }^{3}$ School of Biosciences and Technology, Vellore Institute of Technology, Vellore 632014, India.

Received: 12 December 2019 Accepted: 4 October 2020

Published online: 01 December 2020

\section{References}

1. Ashok SR, Shivananda MK, Manikandan A, Chandrasekaran R (2019) Discovery and synthesis of 2-amino-1-methyl-1H-imidazole-4(5H)-ones as GPCR ligands; an approach to develop breast cancer drugs via GPCR associated PAR1 and PI3Kinase inhibition mechanism. Bioorg. Chem. 86:641-651. https://doi.org/10.1016/j.bioorg. 2019.02.048

2. Bindu B, Vijayalakshmi S, Manikandan A (2019) Discovery, synthesis and molecular substantiation of N-(benzo[d]thiazol-2-yl)-2-hydroxyquinoline-4-carboxamides as anticancer agents. Bioorg. Chem. 91:103171. https//doi.org/10.1016/j.bioorg.2019.103171

3. Kadirappa A, Manikandan A, Sailaja M, Napoleon AA (2018) Synthesis of substituted quinolinyl ether-based inhibitors of PI3K as potential anticancer agents. J. Heterocyclic Chem. 55(7):1669-1677. https://doi.org/10.1002/jhet.3201

4. Muralidharan VP, Manikandan A, Arumugam S, lyer SK (2018) Molecular substantiation and drug efficacy of relatively high molecular weight SBINOLs; appraised as breast cancer medication and PI3 kinase inhibitors. J. Heterocyclic Chem. 55(6):1339-1345. https://doi.org/10.1002/jhet.3166

5. Rajesh KM, Manikandan A, Violet DV (2018) N-substituted hydroxynaphthalene imino-oxindole derivatives as a new class of pi3-kinase inhibitor and breast cancer drug: molecular validation and SAR studies. Chem Biol Drug Des. 91(1):277-284. https://doi.org/10.1111/cbdd.13079

6. Thangarasu P, Thamaraiselvi S, Manikandan A (2018) Unveiling novel 2cyclopropyl-3-ethynyl-4-(4-fluorophenyl) quinolines as GPCR ligands via PI3kinase/PAR-1 antagonism and platelet aggregation valuations; development of a new class of anticancer drugs with thrombolytic effects. Bioorg. Chem. 81:468-480. https://doi.org/10.1016/j.bioorg.2018.09.011

7. Lichterman BL (2004) Aspirin: the story of a wonder drug. British Med J 329(7479):1408 PMCID: PMC535471

8. Petrovska BB (2012) Historical review of medicinal plants' usage. Pharmacognosy Reviews 6(11):1-5. https://doi.org/10.4103/0973-7847.95849

9. Tapsell LC, Hemphill I, Cobiac L et al (2006) Health benefits of herbs and spices: the past, the present, the future. Med. J. Aust. 185:S4

10. Apaya MK, Chang M, Shyur L (2016) Phytomedicine polypharmacology: cancer therapy through modulating the tumor microenvironment and oxylipin dynamics. Pharmacology \& Therapeutics 162:58-68. https://doi.org/ 10.1016/j.pharmthera.2016.03.001

11. Chaudhary T, Chahar A, Sharma JK, Kaur K, Dang A (2015) Phytomedicine in the treatment of cancer: a health technology assessment. J Clin Diagn Res. 9(12):XC04-XC09. https://doi.org/10.7860/JCDR/2015/15701.6913

12. Cheng $Y$, Yang C, Shyur $L$ (2016) Phytomedicine-modulating oxidative stress and the tumor microenvironment for cancer therapy. Pharmacological Research 114:128-143. https://doi.org/10.1016/j.phrs.2016.10.022

13. Jivad N, Rabiei Z (2014) A review study on medicinal plants used in the treatment of learning and memory impairments. Asian Pac J Trop Biomed 4:780-789. https://doi.org/10.12980/APJTB.4.2014APJTB-2014-0412

14. Alés-Martínez JE, Ruiz A, Chacón Jl, Lluch HA, Ramos M, Córdoba O, Aguirre E et al (2015) Preventive treatments for breast cancer: recent developments. Clin Transl Oncol 17:257. https://doi.org/10.1007/s12094-014-1250-2

15. Benoni G, Cuzzolin L (2009) Safety and efficacy of phytomedicines in cancer prevention and treatment. In: Ramawat K (ed) Herbal Drugs: Ethnomedicine to Modern Medicine. Springer, Berlin, Heidelberg, pp 207-220. https://doi. org/10.1007/978-3-540-79116-4_13

16. Gandhi AK, Kumar P, Bhandari M, Devnani B, Rath GK (2017) The burden of preventable cancers in India: time to strike the cancer epidemic. J Egypt Natl Canc Inst. 29:11-18. https://doi.org/10.1016/j.jnci.2016.08.002

17. Schneider AP, Zainer CM, Kubat CK, Mullen NK, Windisch AK (2014) The breast cancer epidemic: 10 facts. The Linacre Quarterly. 81(3):244-277. https://doi.org/10.1179/2050854914Y.0000000027 
18. Vogel CL, Johnston MA, Capers C, Braccia D (2014) Toremifene for breast cancer: a review of 20 years of data. Clinical Breast Cancer. 14:1-9. https:// doi.org/10.1016/j.clbc.2013.10.014

19. Haldosén L, Zhao C, Dahlman-Wright K (2014) Estrogen receptor beta in breast cancer. Molecular and Cellular Endocrinology. 382:665-672. https:// doi.org/10.1677/erc.0.0090001

20. Savithramma N, Linga RM, Suhrulatha D (2011) Screening of medicinal plants for secondary metabolites. Middle-East J. Sci. 8(3):579-584

21. Gacche RN, Shaikh RU, Pund MM (2011) In vitro evaluation of the anticancer and antimicrobial activity of selected medicinal plants from Ayurveda. Asian J Tradit Med. 6(3):127-133

22. Nierenstein M, Potter J (1945) The distribution of myrobalanitannin. Biochem. J. 39(5):390-392. https://doi.org/10.1042/bj0390390

23. Sharma P, Prakash T, Kotresha D et al (2011) Antiulcerogenic activity of Terminalia chebula fruit in experimentally induced ulcer in rats. Pharm Biol. 49(3):262-268. https://doi.org/10.3109/13880209.2010.503709

24. Saleem A, Husheem M, Härkönen P, Pihlaja K (2002) Inhibition of cancer cel growth by crude extract and the phenolics of Terminalia chebula Retz. fruit. J Ethnopharmacol. 81(3):327-336. https://doi.org/10.1016/s03788741(02)00099-5

25. Saha SK, Lee SB, Won J, Choi HY, Kim K, Yang GM, Dayem AA, Cho SG (2017) Correlation between oxidative stress, nutrition, and cancer initiation. International journal of molecular sciences 18(7):1544. https://doi.org/10. 3390/ijms18071544

26. Lee HS, Won NH, Kim KH, Lee H, Jun W, Lee KW (2005) Antioxidant effects of aqueous extract of Terminalia chebula in vivo and in vitro. Biol Pharm Bull. 28(9):1639-1644. https://doi.org/10.1248/bpb.28.1639

27. Shankara BER, Ramachandra YL, Rajan SS, Ganapathy PSS, Yarla NS, Richard SA, Dhananjaya BL (2016) Evaluating the anticancer potential of ethanolic gall extract of Terminalia chebula (Gaertn.) Retz. (Combretaceae). Pharmacognosy Res 8:209-212. https://doi.org/10.4103/0974-8490.182919

28. Saha S, Verma RJ (2016) Antioxidant activity of a polyphenolic extract of Terminalia chebula Retzius fruits. J Taibah Univ Sci 10:805-812. https://doi. org/10.1016/j.jtusci.2014.09.003

29. UKCCCR (1988) Guidelines for the welfare of animals in experimental neoplasia. Br J Cancer. 58:109-113. https://doi.org/10.1038/bjc.1988.174

30. Welsch CW (1985) Factors affecting the growth of carcinogen-induced rat mammary carcinomas: a review and tribute to Charles Brendon Huggins. Cancer Res. 45:3415-3443 PMID: 3926298

31. Parasuraman S, Raveendran R, Kesavan R (2010) Blood sample collection in small laboratory animals. J Pharmacol Pharmacother. 1(2):87-93. https://doi. org/10.4103/0976-500X.72350.

32. Chung JY, Braunschweig T, Hewitt SM (2006) Optimization of recovery of RNA from formalin-fixed, paraffin-embedded tissue. Diagn Mol Pathol. 15(4): 229-236. https://doi.org/10.1097/01.pdm.0000213468.91139.2d

33. Perry $C$, Chung JY, Ylaya $K$, Choi $C H$, Simpson A, Matsumoto KT, Smith WA, Hewitt SM (2016) A buffered alcohol-based fixative for histomorphologic and molecular applications. J Histochem Cytochem. 64(7):425-440. https:// doi.org/10.1369/0022155416649579

34. Chung JY, Braunschweig T, Williams R, Guerrero N, Hoffmann KM, Kwon M, Song YK, Libutti SK, Hewitt SM (2008) Factors in tissue handling and processing that impact RNA obtained from formalin-fixed, paraffin-embedded tissue. J Histochem Cytochem. 56(11):1033-1042. https://doi.org/10.1369/jhc.2008.951863

35. Kakkar P, Das B, Viswanathan PN (1984) A modified spectrophotometric assay of superoxide dismutase. Ind. J. Biochem. Biophys 21:130-132 PMID: 6490072

36. Sinha AK (1972) Colorimetric assay of catalase. Anal. Biochem. 47:389-394. https://doi.org/10.1016/0003-2697(72)90132-7

37. Rotruck JT, Pope AL, Ganther HE, Swanson AB, Hafeman DG, Hoekstra WG (1973) Selenium: biochemical role as a component of glutathione peroxidase. Science 179:588-590. https://doi.org/10.1126/science.179.4073.588

38. Moron MS, Depierre JW, Mannervik B (1979) Levels of glutathione, glutathione reductase, and glutathione-S-transferase activities in rat lung and liver. Biochem Biophys Acta 582:67-78. https://doi.org/10.1016/0304-4165(79)90289-7

39. Ohkawa HN, Ohishi N, Yagi K (1979) Assay for lipid peroxides in animal tissues by the thiobarbituric acid reaction. Anal Biochem. 95:351-358. https://doi.org/10.1016/0003-2697(79)90738-3

40. Omaye ST, Turbull TP, Sauberchich HC (1979) Selected methods for the determination of ascorbic acid in cells, tissues, and fluids. Methods Enzymol. 6:3-11. https://doi.org/10.1016/0076-6879(79)62181-X
41. Reitman S, Frankel S (1957) A colorimetric method for the determination of serum oxaloacetic and glutamic pyruvate transaminase. Am J Pathol. 28:5663. https://doi.org/10.1093/ajcp/28.1.56

42. Samuel DJ, Halsall HB, Amadeo JP, William RH (1993) Determination of serum alkaline phosphatase activity by electrochemical detection with flow injection analysis. Fresenius J Anal Chem 346:859-862. https://doi.org/10. 1007/BF00321305

43. Palaniraja S, Chandrasekaran R, Selvaraj A, Sivakumar A, Manikandan A (2019) Pharmacological explorations of eco-friendly amide substituted (Z)- $\beta$ enaminones as anti-breast cancer drugs. Arch Pharm (Weinheim) 352(1): e1800244. https://doi.org/10.1002/ardp.201800244

44. Manikandan A, Sivakumar A (2017) Molecular explorations of substituted 2(4-phenylquinolin-2-yl) phenols as phosphoinositide 3-kinase inhibitors and anticancer agents. Cancer Chemother Pharmacol 79(2):389-397. https://doi. org/10.1007/s00280-016-3227-z

45. Vivek PM, Manikandan A, Sathiyanarayanan KI (2017) lodine catalyzed the three-component synthesis of 1-(2-hydroxy naphthalene-1-yl) (phenyl)(methyl) pyrrolidine-2-one derivatives: rationale as potent PI3K inhibitors and anticancer agents. Bioorg. Med. Chem. Lett. 27(11):2510-2514. https://doi.org/10.1016/j.bmcl.2017.03.093

46. Romani AMP (2011) Cellular magnesium homeostasis. Arch Biochem Biophys. 512:1-23. https://doi.org/10.1016/j.abb.2011.05.010

47. Kalaiselvi M, Gomathi D, Ravikumar G, Devaki K, Uma C (2014) Therapeutic effect of Ananus comosus peel on breast cancer induced by 7,12- DMBA. Plant Sci Today 1(1):12-20. https://doi.org/10.14719/pst.2014.1.1.8

48. Saraydin SU, Tuncer E, Tepe B, Karadayi S et al (2012) Antitumoral effects of Melissa officinalis on breast cancer in vitro and in vivo. Asian pacific J Cancer Prev. 13:2765-2770. https://doi.org/10.7314/APJCP.2012.13.6.2765

49. Senthilkumar GP, Subramanian S (2007) Evaluation of antioxidant potential of Terminalia chebula, Fruits studied in streptozotocin-induced diabetic rats. Pharmaceutical Biology 45:511-518. https://doi.org/10.1080/13880200701446720

50. Solowey E, Lichtenstein M, Salon S, Paavilainen H, Solowey E, Galski HL (2014) Evaluating medicinal plants for anticancer activity. The Scientific World Journal. 2014:1-12. https://doi.org/10.1155/2014/721402

51. Gacche RN, Shaikh RU, Mahesh MP (2011) In vitro evaluation of the anticancer and antimicrobial activity of selected medicinal plants from Ayurveda. Asian Journal of Traditional Medicines. 6:127-133

52. Catherine NC (2007) Cranberry and its phytochemicals: a review of in vitro anticancer studies. J Nutr. 137:186-193. https://doi.org/10.1093/jn/137.1.186S

53. Ojeswi BK, Khoobchandini M, Hazra DK, Srivastava MM (2010) Protective effect of Thuja occidentials against DMBA-induced breast cancer with reference to oxidative stress. Hum Exp Toxicol. 29(5):369-375. https://doi. org/10.1177/0960327110364150

54. Costa I, Solanas M, Escrich E (2002) Histological characterization of mammary neoplastic lesions induced with 7, 12 dimethyl benz(a) anthracene in the rat- a comparative analysis with human breast tumor. Arch Pathol Lab Med 126:915-927. https://doi.org/10.1043/00039985(2002)126 < 0915:HCOMNL > 2.0.CO:2

55. Ferial M, Sana N, Summya R, Nemat A, Syed KH, Rashid A, Ayaz S, Sarwat S (2015) Terminalia chebula attenuates DMBA/croton oil-induced oxidative stress and inflammation in Swiss albino mouse skin. Toxicol Int 22(1)):21-29. https://doi.org/10.4103/0971-6580.172252

56. Dharmalingam K, Ramakrishnan S, Panchanatham S, Palanivelu S (2016) Chemotherapeutic efficacy of tridham and 1,2,3,4,6-penta-o-galloyl- $\beta$ dglucose on antioxidants status and tumor markers in experimental mammary carcinoma in Sprague-Dawley rats. Asian J Pharm Clin Res 9:202208. https://doi.org/10.22159/ajpcr.2016.v9i5.13247

\section{Publisher's Note}

Springer Nature remains neutral with regard to jurisdictional claims in published maps and institutional affiliations. 